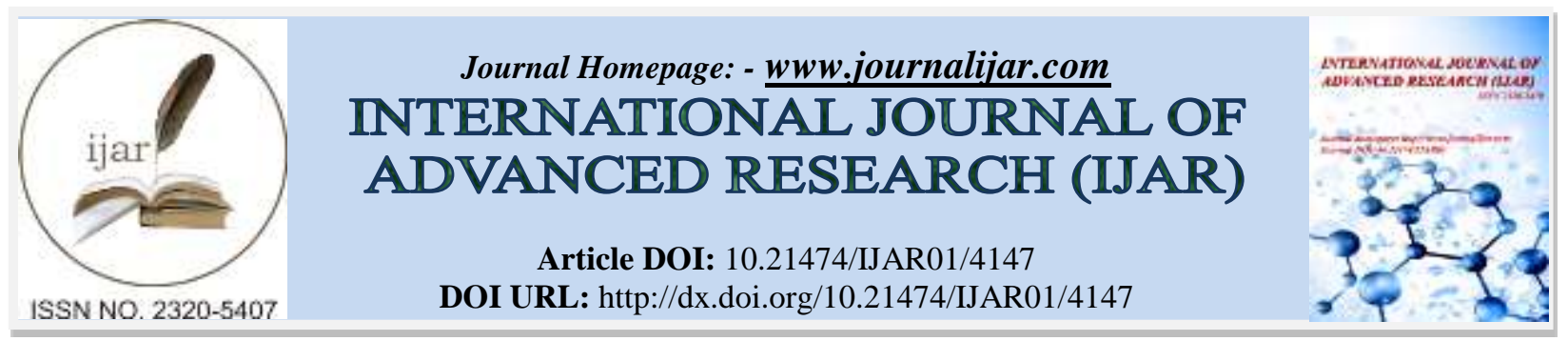

RESEARCH ARTICLE

\title{
LIVED EXPERIENCES OF CHILDREN IN A SELECTED ORPHANAGE.
}

Wulan Novika Ambarsari.

Department of Nursing, Institute of Health Science "Budi Luhur", Cimahi, Indonesia.

\section{Manuscript Info}

Manuscript History

Received: 05 March 2017

Final Accepted: 04 April 2017

Published: May 2017

Key words:-

Children, Lived experiences, Orphanage

\section{Abstract}

This study has surfaced the description of lived experiences of children in a selected orphanage, there is a positive experiences of children, the challangers and problems encountered, and how they can cope with their problems and difficulties during their lived in the orphanage. Methods and ways of working: The study consisted of 7 informant school-aged children which age from 10-13 years old. Qualitative research involves the "researcher as instrument", wherein the researcher's used of self is a primary tool for data collection. The informant would have to answer an interview guide questions by 15 semi structured questions, Interviews were recorded with an audio/video tape and transcribed to produce an accurate representation of the interview proceedings. And observation would also be held to observe attitude and physical appearance of children. The fourth themes in the study were truthfully revealed in their expression of words. The themes which the informants described as A Livable Conditions, Unpleasantly Feeling Process, Hope, and Realization and Acceptance. Based on the findings, the following conclusions were the difficulty of children living in the orphanage has perceived the real condition that they live without their parents and not with their own family, they should compromise their feelings and take the choice, and as they feel more comfortable they would encourage friends. Limitations guardians / caregivers who take care, making children tend to resolve itself any problems and difficulties they encounter during his stay at the orphanage.

Copy Right, IJAR, 2016,. All rights reserved.

\section{Introduction:-}

According Erwintri (2012), the orphanage is a social welfare institution established by the government intentionally or people responsible for doing service, sponsorship, and eradication of neglected children and has a function as a substitute for the role of parents in meeting the mental and social needs of foster children so that they have ample opportunity for physical growth and develop thought until he reaches a mature level of maturity and be able to carry out their role as individuals and citizens in public life.The researcher was able to observe that when children lose a parent or are separated from their home or community, it is very difficult for them to adapt in their new environment and also for fulfillment of their needs. They will not thrive unless the new community they are part of can help them to be emotionally healthy. And also when children are emotionally healthy they have energy to play and learn. It is not easy for them to trust enough to form good relationships with others, without a model and guidance from their parents. 
The number of orphanages throughout Indonesia is between 5000 to 8000 estimated that handle for up to half a million children, one of the highest numbers of orphanages in the world. Indonesian government only has a handful of institutions, more than $99 \%$ of institutions run by the community, especially from religious organizations. In addition to that, the quality of Care in the Social Care Children in Indonesia found that most of the children were sent to orphanages by their families because of economic difficulties and poverty as well as not being able to ensure their children's education. While more than 50\% of children still have one or both parents. Abebe T (2009), revelead that there is a strong correlation between endemic poverty, child destitution and orphan hood, and poverty is not only an economic matter but also a matter that deprives many other individuals and communities of their desired satisfaction in terms of their social and psychosocial, political, physical, spiritiual and economic well being.It is important that an orphanage takes note of the human needs especially the characteristics of children in an orphanage to obtain understanding of their life situation particularly these children in Bandung, Indonesia. Aside from the fact thatthese children receive enough care, needs and can adapt during their stay in the orphanage, this research will also attempt to highlights the needs of children living in other selected orphanage.

This study has surfaced the description of the lived experiences of children in a selected orphanage, there is a positive experiences of children, the challangers and problems encountered, and how they can cope with their problems and difficulties during their lived in the orphanage. The study consisted of 7 informant school-aged children which age from 10-13 years old.

By viewing this Maslow theory, it is important for children at the orphanage who are unable to fulfill adequately their basic human needs because of extreme circumstances as posits by Harper (2003) at Poston (2009) such as diforced of parents, poverty of the family, violence, various forms of child abuse, lack of school, community resources, and emotional abandonment. These Maslow hirearchy can provide support for vulnerable children in the orphan by understanding their basic needs, and these needs will be influenced by the age and level of development of the child.

\section{Materials and Methods:-}

Aqualitative phenomenological design was used to explore and describe the life experiences of children in a selected orphanage in Bandung Indonesia. Qualitative research aims to gather in depth understanding of human behavior. Qualitative research involves the "researcher as instrument", wherein the researcher's used of self is a primary tool for data collection. Phenomenology will used to explore the day-to-day lived experience of children (Macnee, 2008).The informant of the study were children in an orphanage in Bandung Indonesia. The informant included 7 children, ages 10to 13 years old regardless of gender and presently living in the orphanage for at least 6 months, and they must have one or both parents/guardian.By building a relationship of trust with the interviewees, the researcher created an environment that encouraged all the informant to communicate their own interpretation of what life as a children orphanage today is like. Table 1 show the profile of the informant in terms of age and gender.

Table 1:- Informant information.

\begin{tabular}{|c|c|c|}
\hline Informant & Gender & Age \\
\hline I1 & F & 10 \\
\hline I2 & M & 10 \\
\hline I3 & M & 10 \\
\hline I4 & M & 10 \\
\hline I5 & M & 13 \\
\hline I6 & F & 11 \\
\hline I7 & M & \\
\hline
\end{tabular}

The researcher used an interview guide questions developed by the researcher. The tool contains 15 questions reflecting on the life experiences of children in an orphanage. Informant would have to answer the questions via an interviewthat would also be utilized with the help videotaping to ensure that no facts would be missed in the process of data gathering. Observation would also be held to observe attitude and physical appearance of children. The contents of the questions are validated by individuals who are paramount in the field of research to ensure that the data to be collected are valid and substantial.Clarification were used throughout the interviews to avoid misinterpretation of answer. Allowing informant to 'speak their minds' is a good way of discovering detail about complex issues. 
A written permission to conduct this study was given by the researcher to Muhammadiyah Orphanages director. This was done through a courtesy letter. Before conducting the study, a written and verbal consent was taken from the guardians or caretakers of the orphanage. Series of scheduled sessions were done depending on the availability of the informant. The researcher explained the purposed of the studied and the activities to the children. An Observation on the attitudes and behaviors of the informant during the activity was done, and activities were all noted and documented.

Qualitative data analysis used a phenomenological approach to identify and describe the experiences of the informant. To analyze and interpret the text data, qualitative content analysis by Colaizzi was chosen. After transcribing the videotaped interviews, the resercher sent the transcribed interviews through the informant to further check if the transcriptions were correct. After all the interview, the files were given codes. Following each interview, the researcher watched all the videos and heard the tape recorder. This was followed by re-reading and re-watching of the gathered experiences. The researcher analyzed connections between and reflected of significant statements of each informant.

\section{Results:-}

The fourth themes in the study were truthfully revealed in their expression of words. The themes which the informants described as : A Livable Conditions, Unpleasantly Feeling Process, Hope, and Realization and Acceptance.

The positif experiences of childrens living in the orphanages they revealead a livable conditions during they lived in the orphanage, some of conditions of taking pleasure (happy and feel safe with other, feel fun, prayerfulness) and relationship and friendship (relationship, friendship, and family are everything). The livable condition that they feel because of happy a lot of friends, and always playing with their friends, despite their had a good friendship among them.

The challanges and problems encountered by the informants are Unpleasantly feeling process, it is a negative experiences of children living in the orphanage. It includes dissapointed (rejection rule, and loathe), uncomfortable situation (doesn't care with guardians, not happy with family), Inexpediency feeling (feel depressed, feel dissatisfy, feel sad, confused about future and school). That they should adaptation with their feeling, and also with what they feel from the unlpesant situation during they lived in the orphanage.

\section{Key Themes:-}

Theme 1 : A Livable Conditions. A Livable conditions is a condition where they feel fun during a stay at the orphanage. All informants expressed with openness and honesty, about a Livable conditions they felt. For each meeting that has been conducted by researchers, where the average per informant performed three to four meetings, and of every meeting of all informant states "happy" with a different facial expressions, like straight face, smiling, looking down and frowning, embarrassed, or a straight facial expression without a smile.

\section{Taking Pleasure:-}

"I am happy here, i like to have a remote control car and a lot of money."

(Saya senang di sini, saya ingin memiliki sebuah mobil remote control dan banyak uang)

"yes, I am enjoying here, food is always available, clothes are always given, sometimes we had the same dress wanted to have a remote control car, just wanted to be closer to (his friend at the orphanage)."

(iya saya senang disini, makanan selalu tersedia, pakaian selalu diberikan, kadang-kadang kita memiliki pakaian yang sama ingin memiliki mobil remote control, hanya ingin lebih dekat dengan (temannya di panti asuhan)

"I feel happy here (at orphanage), because many guest come and visit us here."

(Saya merasa senang di sini (di panti asuhan), karena banyak tamu yang datang dan berkunjung ke panti ini)

Because the most basic need is for the fundamentals necessary for physical survival, this is indicate that they were feel livable condition during lived at the orphanage.

\section{Relationships and Friendship:-}

Relationships and friendship is an association of an orphan children with people who were connected with them, and being a part of life such as family, friends, social groups. Most of the informants are very happy and enjoying the time when they are with their peers group, playing and being with them.Majority of the informants have positive experience from relationships and friendship. 
"I like it here. I can be closer with friends (mentions the name). I like to stay in orphanage because I have a lot of friends, and it is fun while playing and hanging out with friends and going on holiday with friends...because $i$ feel comfortable if closed with them."

(Saya suka di sini karena bisa lebih dekat dengan teman panti (menyebut nama). Saya ingin tinggal di panti asuhan karena banyak teman-teman, dan menyenangkan sambil bermain dan bergaul dengan teman-teman dan pergi berlibur dengan teman-teman panti karena saya merasa nyaman jika saya dekat dengan mereka)

"I am delighted to meet my sister, because I can talk a lot with her. I feel happy and comfortable living here (orphanages"

(Saya senang bertemu kakak perempuan saya, karena saya bisa berbicara banyak dengan dia. Saya merasa hidup bahagia dan nyaman di sini (panti asuhan))

The statement were short that they were "happy", it indicates that it is the real feelings they feel at that time. Based on gender differences in the ability to express visible feelings. Based on the age,there is visible differences in the ability to express feelings.

Theme 2 : Unpleasantly Feeling. This theme emerged from the informants' responses reflecting on the challenges and problems they had encountered during their stay in the orphanage. "Unpleasantly Feelings", as it is, are the negative experiences brought by challenges and problems stumbled upon by the informants in the orphanage. It also includes psychological safety or a feeling of being secure and respected by other people around oneself, as well as being able to cope with events.

\section{Disappointment:-}

"That's why I do not like if with my mom, I prefer to stay in this orphanage with my friends, can play."

(Itu sebabnya saya tidak suka jika bersama ibu saya, saya lebih memilih untuk tinggal di panti asuhan bersama teman saya, bisa bermain bersama.)

"The thing I do not like is too much rule, or too much ruling and if I get into a fight with a friend in the orphanage, because I do not like when a fight with a friend."

(Hal yang saya tidak suka adalah aturan terlalu banyak, atau terlalu banyak mengatur dan jika bertengkar dengan seorang teman di panti asuhan, karena saya tidak suka ketika berkelahi dengan seorang teman)

"And if a fight with a friend in the orphanage, because I do not like when Iquarrel with a friend."

(Dan jika ada teman di panti asuhan yang bertengkar, karenanya saya tidak suka jika ada teman yang bertengkar.) Statements of the third informant above showed that they feel dissapointed with the experiences they had. In addition, MacArthur (2010) also did a comparison of institutions versus foster homes. Findings revealed that there is no evidence to indicate that group care enhances the accomplishment of any of the goals of child welfare services, and that institutional care is not safer or better at promoting development in orphans and other vulnerable children than foster homes. The study found that institutional care for orphans and other vulnerable children is not stable and does not achieve better long-term outcomes. It is mean Building resilience in orphans and other vulnerable children is very important. According to Kayombo (2007) orphans and other vulnerable children often withdraw and they need someone to listen to their stories so that they can cope better. Children need someone who can encourage their resilience, that is, the ability to personally grow in adverse circumstances.

\section{Uncomfortable Situation:-}

This sub-theme, "uncomfortable situation" emerge from informants' responses such as being not happy and doesn't care with guardians of an during the unpleasantly feeling process. All of the research informants were explaining about unpleasantly feeling so briefly and without pressure.

"I was not happy when $i$ met with the family, because my mother prefers my brother then I (looking down) that's why I do not like if I lived with my mother, I prefer to stay in this orphanage with my friends, I can play with them." (Saya tidak senang ketika saya bertemu dengan keluarga, karena ibu saya lebih memilih dan mencintai saudara saya (melihat ke bawah) itu sebabnya aku tidak suka jika saya dengan ibu saya, saya lebih memilih untuk tinggal di panti asuhan ini dengan teman-teman saya, bisa bermain.)

"Aku di sini tidak bahagia dan tertekan oleh pengasuh di panti asuhan ini. Saya punya pengalaman ketika saya bercerita tentang masalah saya dengan salah satu wali / pengasuh (Ms.X) di sini, dan saya mengatakan kepada pengasuh (Ms.Y) di sini juga jadi aku bertanya penjaga / pengasuh (Ms.Y) untuk tidak menceritakan hal itu kepada siapa pun, tapi satu hari ternyata wali / pengasuh (Ms.X) marah kepada saya, jika saya salah dan juga menuduh saya, saya merasa sedih karena pengasuh (Ms.Y) membocorkan masalah saya. Saya tidak percaya siapa pun di 
panti asuhan ini, termasuk wali / pengasuh jadi jika saya memiliki masalah lagi, aku akan diam itu solusi saya, tidak akan memberitahu siapa pun."

("I'm not happy here and I am depressed because of caregivers in this orphanage. I had an experience when I told him about my problem with one of the guardians/caregivers (Ms.X) here, and I told the nanny (Ms.Y) here too so $i$ asked the guardians/caregivers (Ms.Y) to not tell this to anyone, but one day the guardians/caregivers (Ms.X) came to me and was angry with me, when I was wrong and they accuse me, I feel sad because caregivers (Ms.Y) disclose my problem, I do not trust anyone in this orphanage, including the guardians/caregivers so if I have a problem again, I'll be quite that's my solution, will not tell anybody.")

"Saya punya masalah yang dihadapi pada saat ini, dengan wali saya, saya merasa mereka tidak peduli lagi dengan kebutuhan saya, saya masih mengabaikan mereka, saya tidak peduli juga dengan mereka itu sebabnya saya tidak suka dan tidak nyaman di sini."

("I am encountering some problems at present, with my guardians, i feel they don't care anymore with my needs, I still ignored them, I don't care about them as well.. that's why I do not like it here and I feel uncomfortable here.")

Ideally, the caretaker at the orphanage can provide security and comfort for foster children, where the role of the caregiver is the role of surrogate parents. When they feel sad and depressed, they do not tell and express it to anyone at home, including the caregiver. However,in any conditions that might be better for the children to live in the family and close relatives.

\section{Inexpediency Feeling:-}

It would happen children have inexpediency feeling such as feel depressed, feel dissatisfy, feel sad and confused. In the statements, these were depicted particularly the moment of informant about inexpediency feeling.

"I'm not happy here and pressured by caregivers in this home. I had an experience when I told him about my problem with one of the guardians/caregivers (Ms.X) here, and I told the nanny (Ms.Y) here too, so $i$ asked the guardians/caregivers (Ms.Y) not to tell this to anyone, but one day turns guardians/caregivers (Ms.X) angry to me, if I was wrong and also accused me."

(Aku di sini tidak bahagia dan tertekan oleh pengasuh di rumah ini. Saya punya pengalaman ketika saya bercerita tentang masalah saya dengan salah satu wali / pengasuh (Ms.X) di sini, dan saya mengatakan kepada pengasuh (Ms.Y) di sini juga, jadi aku bertanya penjaga / pengasuh (Ms.Y) untuk tidak menceritakan hal itu kepada siapa pun, tapi satu hari ternyata wali / pengasuh (Ms.X) marah kepada saya, jika saya salah dan juga menuduh saya.)

The informant above faced many challenges; inexpediency feelingthat involve the lack of parental guidance, love, care, and acceptance in the new families they join. They also face social problems, which include the lack of supportive peer groups, and role models from guardians (Skinner, 2007).

\section{Theme 3 : Hope:-}

Hope refers to a person's constant striving to realize the potential within and to develop inherent talents and capabilities. The theme "Hope" is how the children cope with their problems and difficulties during lived in the orphanage.

\section{Caring:-}

These sub-theme proove that children an orphanage can cope with their problems and difficulties with have sense of belonging of orphanage and be caring with others. Aside children need to be heard, and need to learn to express their feelings in an appropriate manner. At times, children's emotional needs may include assisting them to cope with especially difficult circumstances.

According Pillateri (2007), school-age are learning to give a present without receiving one in return or doing a favor without expecting a reward is also a part of this process, and chilren also show empathy (caring) toward others as early. Fourth perceptible testimonials regarding this were voiced out:

"Then later when i grow up, I want to be able to take care of this orphanage"(Kemudian ketika saya dewasa nanti, saya ingin bisa mengurus panti asuhan ini.)

"And I would like to give funds for orphanage when I grow up"

(Dan ingin memberikan dana untuk panti asuhan ketika saya besar nanti.) 
Life experience in the orphanage had taught them about the meaning of sharing and empathy. The informant above have a similar background about their family, where they know the reason placed in an orphanage, as they feel alienated or deliberately placed by their parents for reasons they still have not understood until now. So children who receive affection, stimulation, and support in early childhood have a good foundation for growth and development, are more able to cope with challenges, are better at overcoming disadvantages, and making positive contributions to the society.

\section{Desirability Situation:-}

Being aware of the dynamics of expectation value, behavior can assist one in developing within orphans and vulnerable children those behaviors most conducive to healthy living. Therefore, children in the orphanage need to be motivated as a means of encouraging their inner resources. The Informant below revealed clearly about their hopes for the future.

"My dream is to be a cop and I would like to give fund for orphanage when I become big, because I want my friends to feel happy during their stay in the orphanage (moody)."

("Cita-cita saya dan berharap nantinya adalah untuk menjadi polisi, dan ingin memberikan dana untuk panti asuhan ketika saya besar, karena saya ingin teman saya merasa senang selama mereka di panti asuhan (murung).")

"The most important person to me is Ms. R (orphanage guardians) because she has been keeping me well like my own mother, and treat me well)"

("Orang yang paling penting bagi saya Ms $R$ (panti asuhan wali) karena ia telah menjaga saya dengan baik seperti ibu saya sendiri dan memperlakukan saya dengan baik.)

Relationships are very important in the development of children, because they create a bond between the children and the loved ones especially in their early years. When children are denied interpersonal involvement, they lose intrinsic motivation, but if someone is responsive and demonstrates that he/she cares about the children's well-being, they show high intrinsic motivation (MacArthur, 2010).

Where according to research (Farooqi, 2009) differences in self-determination of Orphan Children and Children living with their Parents, findings that the orphan children reported lower self-determination than the children living with their parents. According to that statement, acceptance of themselves be important for children's at orphanage.

\section{Theme 4 : Realization and Acceptance:- Compromise and Receptive:-}

The theme "Realization and acceptance" also answers and reflects on how the children cope with their problems and difficulties during their stay in the orphanage. School age children have ability to adapt through processes to fit what is perceived, but they are still limited in their ability to understand others views they may interpret something as being right because it is good for them, not because it is right for humanity as a whole (Pillateri, 2007).

To bring out the best responses, their actual encountered of cope were examined through the two elements of realization and acceptance which are as follows : compromise and receptive.

\section{Compromise:-}

To compromise is to make a deal between different parties where each party gives up part of their demand. It meansthat all informantsfind agreement through mutual acceptance, often involving variations from an original goal or desire. Turner (2013) cited, compromise actually is a process of giving and taking, a sign of strength not weakness, and an avenue toward a win - win situation for everyone involved.

"Saya akan mencoba menerima hidup di panti ini, daripada tinggal bersama ayah dan ibu. Aku akan mengikuti semua aturan dan jadwal yang ada di panti asuhan ini"

("I would try to accept living in this orphanage, rather than living with my father and mother. I will follow the rule and the schedule in this orphanage, even it is hard to me")

Negotiation by definition implies the right to say no, to reject the offer, walk away and refuse the deal. Compromise however, involves giving and taking. The fact that there will be an agreement is assumed from the start. The only question is what form the agreement will take, and who will give way on what. 


\section{Receptive:-}

Receptive is capable of receiving something and ready to receive and accept new things. Informant reveal about their acceptance as the orphanage children. The expression on their faces as they express acceptance of themselves, they all looked glum and down. Their eyes were filled with tears.

"I accept the conditions of today, when I was a child living in an orphanage, and not living with my parents (glum facial expressions and tone of voice answered slowly and small). I would accept living in this orphanage, rather than live with my father and mother however, I accept the current conditions, I have to stay in the orphanage, even with a heavy heart."

("Saya menerima kondisi saat ini, di mana saya adalah seorang anak yang tinggal di panti asuhan, dan tidak tinggal bersama orang tua saya (murung ekspresi wajah dan nada suara menjawab perlahan dan kecil). Saya akan menerima hidup di panti ini, daripada tinggal bersama ayah dan ibu. Namun, saya menerima kondisi saat ini, saya harus tinggal di panti asuhan, bahkan dengan berat hati.")

\section{Informant \# 3:-}

"Sejauh ini saya tidak merasa tertekan, sekadar ketika sedih saya menonton tv dan bermain di kamar tidur sedihnya biasanya ketika berdebat atau bertengkar dengan teman."

("So far I do not feel depressed, just plain when I am saddened I watch TV and play at the bedroom, I'm usually sad when arguing or fight with friend.")

The statements of the informant above, explained that theywere familiar with the conditions and situations around them during at the orphanage

Informant \#6 :

"I don't feel inferior of my status as orphan, I'm not shy with my friends at school, I often invite school friends to play in the orphanage, and my friends understand my condition."

("Saya tidak merasa minder dengan status saya sebagai anak yatim, saya tidak malu dengan teman-teman saya di sekolah, saya sering mengundang teman-teman sekolah untuk bermain di panti asuhan, dan teman-teman saya mengerti kondisi saya.")

It is obvious in a wonderful feeling of inner balance, grounded on self-acceptance and a healthy, comforting selfrespect towards (Farooqi, 2009). Success needs involve developing enough confidence in achievement to be willing to try new things, to have some self-respect and a degree of independence and freedom appropriate to the child's age(Francis, 2010).

\section{Summary of Fingdings:-}

1. The positive experiences of children living in the orphanages are that they revealead a livable conditions during their stay in the orphanage, some of conditions of taking pleasure (happy and feel safe with other, feel fun, prayerfulness) and relationship and friendship (relationship, friendship, and family are everything). The livable condition that they feel because of happy a lot of friends, and always playing with their friends, even their good friendship among them.

2. The challanges and problems encountered by the informants are unpleasantly feeling. It is a negative experience of children living in the orphanage. It includes (1) dissapointment (rejection, rule, and hatred), (2) uncomfortable situation (doesn't care with guardians, not happy with family), and (3) inexpediency feeling (feel depressed, feel dissatisfy, feel sad, confused about future and school). They have to adapt or adjust in the environment in terms of their feelings and their relationship with the people surrounding them in the orphanage. Caregiving in orphanages found to be very less implemented. Almost all of the focus is to meet the needs of everyday materials while the emotional and developmental needs children are less considered. When children were place at the orphanage, relationships with families tend to be very limited. Orphanage allow children to go home only once a year at the holiday or Id Mubarak days, or if they want it.

3. Informantscope with their problems and difficulties with hope and realization and acceptance. Informant revealed clearly about hope, such as caring (sense of belonging) and desirability situation (expectation, desires, need communication, need comfortable and safety, need the important and meaningful person, need for familiar). While living in the orphanage, the experiences had taught them about the meaning of sharing and empathy to 
achieve their ideals. Nevertheless, an interaction with the family is rarely to be done. But still, they need to be loved and and cared forby the people who brought them in this world.

4. Realization and acceptance during their stay in the orphanage is quite hard to achived because they have to be receptive (receptive the real condition, and accept facilities at the orphanage), and compromise (bargaining feelings, follow and obey the rule and schedule, take choice). Aside from accepting the real conditions in the orphanage, children have to have a good coping mechanism to cope their problems and difficulties.

\section{Conclusion:-}

Thepreceding findings led to the following conclusions:

1. The difficulty of children livingin the orphanage has perceived the real condition that they live without their parents and not with their own family, but fact that their lived with stranger people. They have to follow and obey the rules and regulations at the orphanage, compromise with the real condition that they do not realized before, finally they should compromise their feelings and take the choice, despite their rejection and disappointments about their family. Andas they feel more comfortable they would encourage friends, like playing and communication together among those.

2. Limitations guardians / caregivers who take care, including guardians / caregivers who have received professional training, making children tend to resolve itself any problems and difficulties they encounter during his stay at the orphanage. Caregivers and guardians are also part of the social support network for orphans and other vulnerable children because they take on theresponsibility for parenting those children when there is no one else in the family willing to do so. There is almost no assessment on the needs of children both before, during, and after they lived in the orphanage. Criteria for the selection of children and the recruitment practices focus on school-age children, the poor, and the less fortunate families. All management and the guardians/caregivers are not really aware of the difficulties faced by these children and should work hand in hand to help them adjust in a new family, so they can fullfiled all needs.

3. Friends are also part of the social support for orphans, because they socialize with these orphan children and give them moral support and encouragement when the children need someone to comfort them.

4. The life experiences of the participants during their stay at the orphanage gave meaning in their lives. Rejection at first, but later adaptation and survival and become familiar with. Challenged by the difficulties encountered, but thankful for the life changing experience they had.

\section{Recommendation:-}

Based from the foregoing findings and conclusions the following recommendations are forwarded:

1. For nursing education, can be used as basic data for developing practice guidelines nursing students for the orphan childrens assessment, especially school age children. Beside that working and collaborate with social department or other health professionals such as psychologists to organize and improve the quality of service for children such as assigning main Officer of Counseling and Consultation to facilitate and solve the needs of the children during their stay in the orphanage. The preparation of adaptive measures needed by children, including preparation for the consultation, interaction, sosialization services.

2. For orphanages, to strengthen the socio-emotional support systems coming from different families, and social culture in the orphanage such as dormitory monitors from management directly, for cope what the problems and issued coming from the children. Support system needs from the orphanage for children to enhanced the capability and reception to the real condition. Hold regular meetings between all caregivers/guardians with management at least 1 month to figure out what problems arise in children, and also how to solve the problem. In addition to the caregiver, management also hold regular meetings with the orphan childrens, with doing approach intensively so that they feel the attention and affection of nursing management, in addition to physical needs are provided.

3. For orphanages, to develop education and training for guardians/caregivers could be implemented to enhance skills, knowledge, and attitude of the guardian, to understand how they can face and solve all the need of the children, and be capacitated in the programmes and legislation that protect children's rights. Forms of training would be given such as training on teaching and care to children. Implementation of the training is will be done in partnership with social department or health department, which is routinely given at least 1 month.

4. Management orphanage make a regularly scheduled at least every 3 months, to hold a meeting with childrens parents or family foster. It is also recommended that families be guided on coping strategies, because it is important on strengthening coping mechanisms where children already have experience, and "safety" support provided where caregivers cannot cope. The needs of love and belongingness is the situation of parents that must 
care for too many children should be supported to look after their children while they are still alive, so that their children will feel proud of their presence.

5. To improve achievement in education and addressing anxiety for school homework, held every day discussion session, guided by the guardians / caretaker or from the management. In addition, there was cooperation with educational institutions to develop the skills and education kognitive, cooperation with educational institutions such as the computer, so that children can learn computers in orphanage. And working with training institutions to enhance afective and motor development, such as sports training, martial arts, drawing, art (sing, dance), so the child can have more skills.

6. To cope feeling unpleasantly procees, the management of working together with several educational institutions, conduct activities that lead so orphans can feel happy and happy during their stay in the orphanage, by carrying out activities such as recreation to nature, camping, fishing, climbing hills or mountains, swimming, going to the museum or zoo. This activity can be scheduled every school holiday.

7. For future research needs to place a great emphasis on the differences, in expectation and problems of children depending in their gender, ethnicity, for provides a better understanding the experiences of children and how they can survive and adapt as an orphan.

\section{References:-}

1. Bowden, Vicky R \& Greenberg, Cindy Smith. (2008). Pediatric Nursing Procedures second Edition. Philadelphia : Lippincott Williams \& Wilkins.

2. Hockenberry, Marilyn. (2008). Nursing Care of Infants and Children $8^{\text {th }}$ Edition. Missouri : Mosby

3. Macnee, Carol L.,McCabe, Susan. (2008). Understanding Nursing Research : using research in evidencebased. China : Lippincott Williams \& Wilkins

4. Pillitteri, Adele. (2007). Maternal \& Child Health Nursing ; Care of the Childbearing \& Childrearing Family $5^{\text {th }}$ Edition. Philadelphia : Lippincott Williams \& Wilkins.

5. Polit, Denise F.,Beck, Cheryl T. (2008). Nursing Research :Generating and Assessing Evidence for Nursing Practice. Philippines : Lippincott Williams \& Wilkins

6. Richter, L, Foster, G \&Sherr, L. (2008). Where the heart is: meeting the psychosocial needs of young children in the context of HIV/AIDS. Netherlands: Bernard van Leer Foundation.

7. UNAIDS/UNICEF. (2007). Children Orphaned by AIDS: Front-line Responses from Eastern and Southern Africa. New York: UNAIDS / UNICEF

8. Streubert, Helen J and Carpenter, Dona R. (2011). Qualitative Research in Nursing Advancing the Humanistic Imperative. China : Lippincott Williams \& Wilkins

9. Wong's. (2007). Nursing Care of Infants and Children $8^{\text {th }}$ edition. Singapore : Elsevier Pte Ltd

10. Abebe T (2009), orphanhood, poverty and care dilem : review of global policy trend. Norway : Trendheim. On Journal of Sustainable Development in Africa (Volume 12, No.4, 2010) ISSN: 1520-5509Clarion University of Pennsylvania, Clarion, pennsylvania

11. Farooqi and Intezar. (2009). Differences in Self-Esteem of Orphan Children and Children libing with their Parents . J.R.S.P., Vol. 46, No. 2

12. Hablemitoglu,Özkan, and Purutçuoglu. (2010). The Assessment of the Housing in the Theory of Maslow's Hierarchy of Needs. European Journal of Social Sciences - Volume 16, Number 2 (2010)

13. Stein, Martin. (2012). "Challenging cases :Biopsychosocial pediatric". Pediatric official Journal of The American of Pediatric

14. Kayombo, Edmund J and Mbwambo, Zakaria H. (2007). Role of Traditional Healers in Psychosocial Support in Caring for The Orphans : A case of Dar-es Salaam City, Tanzania. Journal of Ethnobiology and Ethomedicine 2005;1:3

15. Rooyen, Dalena Van. (2012). "The experiences of AIDS orphans living in a township".AOSIS open Journal Departement of Nursing Science Nelson Mandela

16. Al Jufri, Segal (2010). Panduan Program KesejahteraanSosialAnakno :15A/HUK/2010. Ministry of Social Republic of Indonesia: Jakarta

17. Farhan, Abu. (2010). Kepercayaan Diri. Jakarta

18. Gilborn, L, Apicella, L, Brakarsh, J, Dube, L, Jemison, K, Kluckow, M, Smith, T \& Snider, L. (2007).Orphans and vulnerable youth in Bulawayo, Zimbabwe: an exploratory study of psychosocial well-being and psychosocial support, Horizons final report. Washington, DC: Population Council.

19. Gumede, Phiwayinkosi Richmond. (2009). The Psychosocial Well-Being of Teenaged Orphans in a Rural Community, Kwazulu-Natal. University of South Africa 
20. Haludilu, Petrina Nangula. (2007). Basic Human Needs of Orphans and Other Vulnerable Children and Fulfillment in Windhoek. University of Namibia

21. Poston, Bob. (2009). An exercise in personal exploration : Maslow's Hirearchy of Needs. Association of Surgical Technologist (Publications@ast_org)

22. Skinner, D ,Davids, A, Matlhaku, T, Phakedi, R, Mohapeloa, P, Romao, S, Mdwaba, T, Kazi, N, \&Mundondo, J. (2007). A reflection on values, principles and organisational issues. Cape Town: HSRC

23. Stalker, Peter. (2008). Millennium Development Goals 2008.Bappenas UNDP

24. Walker, Lynn. (2007). Psychosocial Support training Manual. Farm Orphan Support Trust (F.O.S.T)

25. Erwintri, (2012, october 28). Pengertian Panti Sosial Asuhan Anak. Retrieved January, 15 2013, from http://ewintribengkulu.blogspot.com/2012/10/pengertian-panti-sosial-asuhan-anak.html

26. Francis, Meagan. (2010). Child's Hierarchy of Needs. Retrieved January 16, 2013 from http://www.phdinparenting.com/2010/01/14/childs-hierarchy-of-needs/

27. Karnadi.(2009).

PengaruhJenisKelamindanKreativitasTerhadapKemampuanMengemukakanPendapatAnakKelasRendah di SekolahDasar.Retrieved January 16, 2013 fromhttp://isjd.pdii.lipi.go.id

28. Mazhar, U. (2008). Self-esteem, Human development foundation,Retrieved on January 20, 2013 fromhttp://www.yespakistan.com/wellness/self-esteem.asp.

29. MacArthurand John.(2010). Early Foster Care Boosts Quality of Institutionalized Children's Ties to $\begin{array}{llll}\text { Caregivers.Retrieved November } & \text { 20, 2012from }\end{array}$ http://www.sciencedaily.com/releases/2010/02/100205081819.htm

30. Nasaba, R, Defilippi, K, Marston, J \&Musisi, S. (2007). A clinical guide to supportive and palliative care for HIV/AIDS in Sub-Saharan Africa: care of children and adolescents. Retrieved November 28, 2012 from http://www.fhssa.org/i4a/pages/Index.cfm?pageID=3361

31. Sudrajat, Tata. (2008). Kurangnya Pengasuhan di Panti Asuhan. Retrieved August 20, 2012 from http://www.depsos.go.id/modules.php?name=News\&file=print\&sid=674

32. Turner, Russell. (2013). Should we compromise with our children?. Retrieved March, 2013 from http://www.brainy-child.com/article/compromise-with-children.shtml. 